OSEANOLOGI DAN LIMNOLOGI DI INDONESIA

Print ISSN: 0125-9830 Online ISSN: 2477-328X

Nomor Akreditasi: 712/AU3/P2MI - LIPI/10/2015

http://jurnal-oldi.or.id

\title{
Grouping of Meroplankton Habitat in Jakarta Bay and Seribu Island
}

\section{Pengelompokan Habitat Meroplankton di Teluk Jakarta dan Kepulauan Seribu}

\author{
Reny Puspasari ${ }^{1}$ and Aisyah ${ }^{2}$ \\ ${ }^{1,2}$ Fisheries Research Center \\ Email: reny.paksi@gmail.com
}

Submitted 18 May 2017. Reviewed 3 November 2017. Accepted 7 February 2018.

\begin{abstract}
Jakarta Bay is an estuarine ecosystem and facing the small island groups of Seribu Island. Jakarta Bay is known as nursery ground for many marine biotas, determined by numerous numbers of meroplankton. The distributions of meroplankton are highly influence by environmental conditions of Jakarta Bay and Seribu Islands. This research objective was to analyze the habitat preferences of some meroplankton groups such as shrimp, mollusk, crab and fish larvae in Jakarta Bay and Southern Seribu Islands. Fish larvae sampling was conducted in 13 stations that categorized into estuarine and small island stations in Jakarta Bay and Southern Seribu Island, combination of seven estuarine stations and six small island stations. The results found that there was a variation on the distribution and composition of meroplankton in sampling area. There were six groups of marine meroplankton, namely shrimps, mollusk, crabs, fish, jelly fish and squid larvae in Jakarta Bay and Seribu Island. The abundance of shrimp, mollusk and fish larvae is higher in April than August. The abundance of crab larvae is higher in August than April, while the others are found in small number both in April and August. Shrimps, fish and mollusks larvae have no specific preferences in habitat used, however they mostly used small island stations as their habitat compare to estuary, which has high temperature and salinity
\end{abstract}

Keywords: distributions, habitat, Jakarta Bay, meroplankton, Seribu Islands

\begin{abstract}
Abstrak
Teluk Jakarta tergolong ekosistem estuary, yang menghadap kepada sekumpulan pulau-pulau kecil di Kepulauan Seribu. Teluk Jakarta merupakan daerah asuhan bagi biota laut, yang ditandai oleh banyaknya meroplankton yang ditemukan di wilayah tersebut. Penyebaran meroplankton sangat dipengaruhi oleh kondisi lingkungan Teluk Jakarta dan Pulau Seribu. Terdapat variasi sebaran dan komposisi meroplankton di daerah pengamatan. Tujuan dari penelitian ini adalah untuk menganalisa habitat beberapa kelompok meroplankton seperti udang, moluska, kepiting dan larva ikan. Pengumpulan sampel larva dilakukan di 13 stasiun pengamatan yang mewakili estuary dan pulau pulau kecil di Teluk Jakarta dan Pulau Seribu bagian selatan, meliputi tujuh stasiun estuary dan enam stasiun pulau kecil. Hasil menunjukan bahwa terdapat enam kelompok meroplankton laut, meliputi larva udang, moluska, kepiting, ikan, ubur-ubur dan larva cumi. Kelimpahan udang, moluska dan larva ikan tinggi pada April dibandingkan dengan Agustus. Kelimpahan larva kepiting menunjukan hal sebaliknya, yaitu tinggi pada Agustus dibandingkan dengan April. Sedangkan larva yang lain ditemukan dalam jumlah kecil pada bulan-bulan tersebut. Larva udang, ikan dan moluska tidak memiliki habitat khusus, namun keberadaan mereka kebanyakan dijumpai pada pulau-pulau kecil dibandingkan dengan estuary, dimana kondisi lingkungan seperti suhu dan salinitas pada ekosistem tersebut relatif lebih tinggi.
\end{abstract}

Kata kunci: distribusi, habitat, meroplankton, Pulau Seribu, Teluk Jakarta 


\section{Introduction}

Early life phase of some marine biota is the most critical phase in their life history. Their survival rate is mostly low due to the high predation, the availability in appropriate food source, physical condition and habitat preference to grow up. Those physical and biological conditions at the time egg and larvae development may differ time to time and between locations. The pattern and distribution of egg and larvae are initially set by the adults, but a combination on physical and biological factors (water movement, temperature, distribution, abundance of prey and predators) act directly on larvae to influence their distributions, abundance, growth and survival (Heat 1992).

Jakarta Bay is a big estuarine system, receiving run off from 13 rivers, facing a small island groups namely Seribu Islands. The environmental or oceanographic conditions of Jakarta Bay are influencing by Seribu Islands water quality. However there is a big different on the physical condition between both those ecosystem. Estuary tends to have low salinity and high TSS, and mangroves predominant plants, while in small island, salinity is high, TSS is low and seagrass meadows are predominant vegetation. There are ecological connectivity between Jakarta Bay and Seribu Islands. Jakarta bay and Seribu Island serve as nursey ground for many marine biotas. Nastiti et al. (2010) found high abundance in fish larvae in Jakarta Bay, and Puspasari et al. (2013) found high abundance of fish larvae in Seribu Islands. The distribution of meroplankton in Jakarta Bay and Seribu Island is much dispersed. Some species has a preference in certain conditions to grow, while others are found in numerous numbers everywhere. The research objective is to analyze the grouping pattern of meroplankton in habitat selection, these study allow us in knowing the spatial and temporal patterns in distribution and abundance of meroplankton in Jakarta Bay and Southern Seribu Islands.

\section{Methods}

\section{Sample collection and Analysis}

Meroplankton samples were collected during two surveys carried out in April and August 2014 in Jakarta Bay. The sampling scheme was based on ecosystem type, such as estuaries and coral reef ecosystem. There were seven estuarine stations and six small island stations, which represent three typical ecosystems such as coral reef, sea grass and mangroves. The list of sampling stations is presented in Table and Figure 1.

A bonggo net sampler of $60 \mathrm{~cm}$ diameter and $500 \mu \mathrm{m}$ mesh size was used on both field sampling. The net was towed during 10 minutes using a vessel at speed of $1-2$ knot. The volume of water filtered was determined by multiplying the speed of vessel with the time of withdrawal and the area swept. The depth of the net was arranged by using weight and buoy, sampling depth approximately below the surface. Volume of water filtered is used to standardize catches to numbers per square meter. In the laboratory, meroplanktonic species were sorted then counted and identified into group of taxa then continue to family level. Meroplankton in this research referred to any kind of marine organism larvae. Temperature and salinity were measured manually using thermometer and refractometer. 
Table 1. Sampling stations

Tabel 1. Stasiun pengamatan

\begin{tabular}{|c|c|c|c|}
\hline Stations & & sitions & Type of \\
\hline Muara Marunda & S 6 $4^{\prime} 51,83$ & E $106^{\circ} 58^{\prime} 2,92$ & Estuary \\
\hline M. Gembong & $S 6^{\circ} 1^{\prime} 45,18$ & E $106^{\circ} 59^{\prime} 7,51$ & Estuary \\
\hline M. Bahagia & S 5 $56^{\circ} 24,96$ & E $106^{\circ} 59^{\prime} 23,95$ & Estuary \\
\hline M. Buting & S 5 $54^{\circ} 52,42$ & E $107^{\circ} 1^{\prime} 30,52$ & Estuary \\
\hline Pulau Damar kecil & $S 5^{\circ} 59^{\prime} 3,26$ & E $106^{\circ} 51^{\prime} 15,76$ & Small Island \\
\hline P. Damar Besar & $S 5^{\circ} 57^{\prime} 4,86$ & E $106^{\circ} 50^{\prime} 21,78$ & Small Island \\
\hline P. Tidung & $S 5^{\circ} 48^{\prime} 26,05$ & E $106^{\circ} 31^{\prime} 23,21$ & Small Island \\
\hline P. Lancang & S 5 $56^{\circ} 14,78$ & E $106^{\circ} 36^{\prime} 6,11$ & Small Island \\
\hline P. Rambut & $\mathrm{S} 5^{\circ} 58^{\prime} 1,76$ & E $106^{\circ} 41^{\prime} 37,78$ & Small Island \\
\hline P. Pari & $\mathrm{S} 5^{\circ} 51^{\prime} 53,20$ & E $106^{\circ} 35^{\prime} 37,13$ & Small Island \\
\hline Tanjung Anom & S 5 $59^{\circ} 52,01$ & E $106^{\circ} 39^{\prime} 22,23$ & Estuary \\
\hline Tj. Rebo & $\mathrm{S} 6^{\circ} 2^{\prime} 12,50$ & E $106^{\circ} 42^{\prime} 50,10$ & Estuary \\
\hline M. Kamal & $S 6^{\circ} 5^{\prime} 27,46$ & E $106^{\circ} 43^{\prime} 55,37$ & Estuary \\
\hline
\end{tabular}

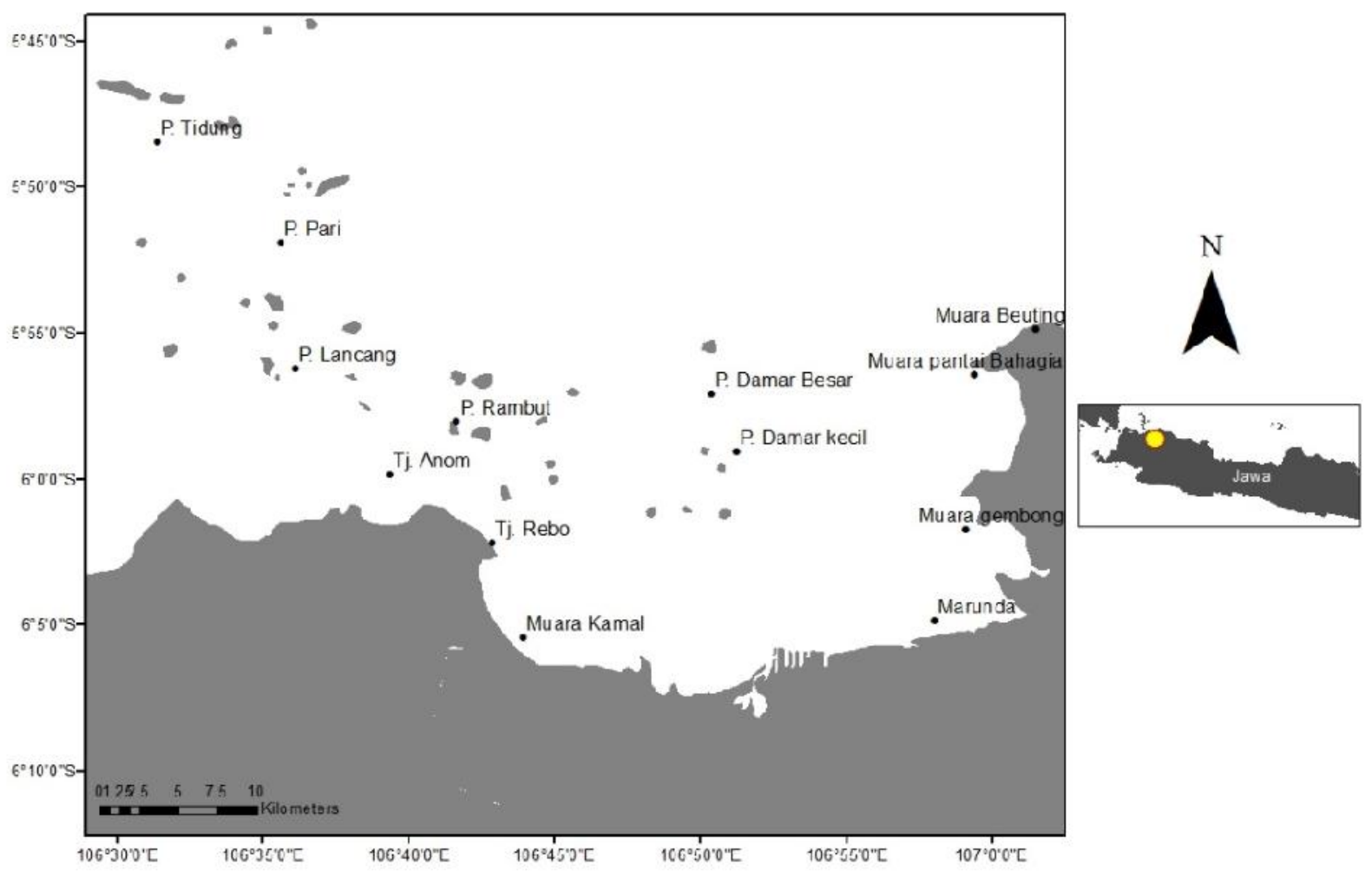

Figure 1. Research location in Jakarta Bay and Southern Seribu Islands. Gambar 1. Lokasi penelitian di Teluk Jakarta dan Pulau Seribu bagian Selatan. 


\section{Multivariate Analysis}

Sampling sites were compared to define areas with similar taxa composition. The taxa by sampling site matrix, expressed as abundance values (number of individuals per $\mathrm{m}^{3}$ ), was analyzed using both cluster analysis and metric multidimensional scaling (MDS) (Somarakis et al. 2002). MDS analysis requires a matrix of measures of associations. In this paper, matrix is a description of meroplankton species associations. Data were transformed using the $\log _{10}(x+1)$ function to enhance the contribution of the less abundant species. Following the cluster analysis, the data sets were further subjected to MDS ordination. Prior to ordination, "outlier" sample sites identified with cluster analysis were removed from the data set to obviate problems associated with such outliers, e.g. biasing or dominating the ordination often compressing the distribution of the remaining sites.

Image mapping analysis was conducted to explain more on group agglomerated. Image mapping analysis shows the number of adjacent attribute points in every group. Attributes refer to the type of larvae (fish, shrimps, mollusk, crab, jelly fish and others). Adjacent attribute point shows the similarity of any stations within groups (Herman 2010).

\section{Results}

\section{Environment Condition}

Sampling stations were divided into two categories, there are: seven estuarine stations and six small island stations. Average temperature on April $\left(22.4^{\circ} \mathrm{C}\right)$ was lower than August $\left(28^{\circ} \mathrm{C}\right)$, and salinity on April was $21.9 \mathrm{ppt}$, while salinity on August was 26.4 ppt (Figure 2). Estuarine stations showed lower average temperature and salinity than small island stations.

\section{Abundance of Zooplankton}

Zooplankton is a food source of meroplankton (marine larvae), most of marine larvae feed on micro and meso zooplankton. Zooplankton abundance in 13 sampling stations are describe in Figure 3.

Figure 3 shows that zooplankton abundance was higher in August $(117,007.42$ ind $\left./ \mathrm{m}^{3}\right)$ than April $\left(96,105.76 \mathrm{ind} / \mathrm{m}^{3}\right)$. The highest zooplankton abundance occurs in Buting and Marunda Estuaries, respectively. Totally, all estuarine stations have higher abundance $(10,639$ ind $/ \mathrm{m}^{3}$ ) of zooplankton compare to small island stations $\left(3,605.5 \mathrm{ind} / \mathrm{m}^{3}\right)$.

\section{Taxonomic Composition, Abundance and Distribution}

Meroplankton collected by using a bongo net composed of six groups of larvae that were shrimp, fish, mollusk, crab, squid, jelly fish and fish egg. Shrimp larvae were dominating the meroplankton composition both in April and August (Figure 4 and 5). In April, shrimps larvae comprised almost $98 \%$ of total larvae; another 2 $\%$ are mollusks, crabs, fishes, squids and jelly fishes. While in August, domination of shrimps larvae was decreased, meroplankton comprised of shrimp larvae (78\%), fish larvae (10\%), crab larvae (4\%), egg (4\%), both of mollusk and squid larvae (4\%). Total larvae found in April was 92.3 times higher than in August. The abundance distribution of each group of larvae is described in Figure 4 and 5.

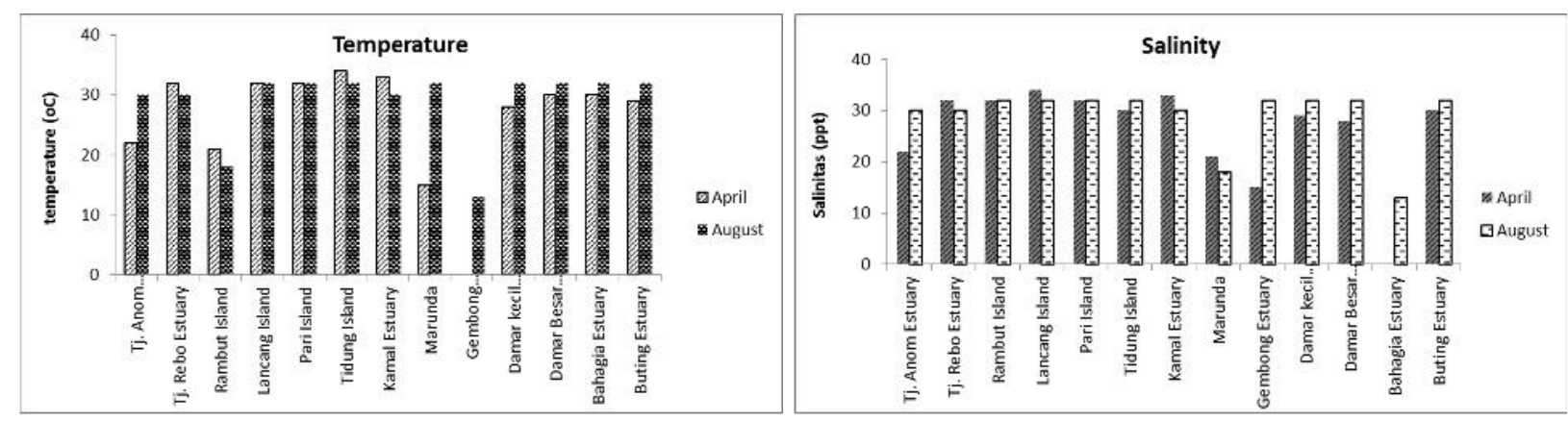

Figure 2. Profile of temperature and salinity on April and August.

Gambar 2. Profil suhu dan salinitas pada Bulan April dan Agustus. 


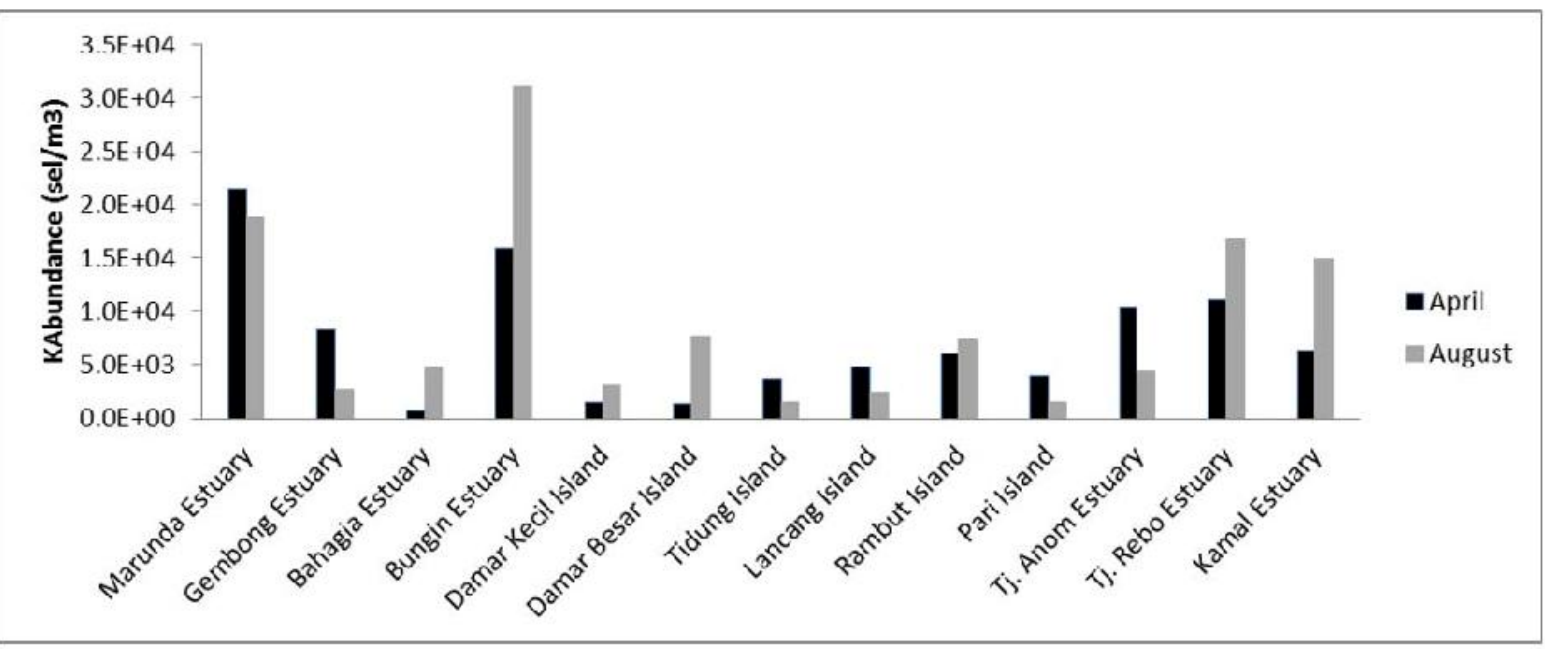

Figure 3. Zooplankton abundance in estuary and small islands stations.

Gambar 3. Kelimpahan zooplankton pada stasiun pulau kecil dan estuari.
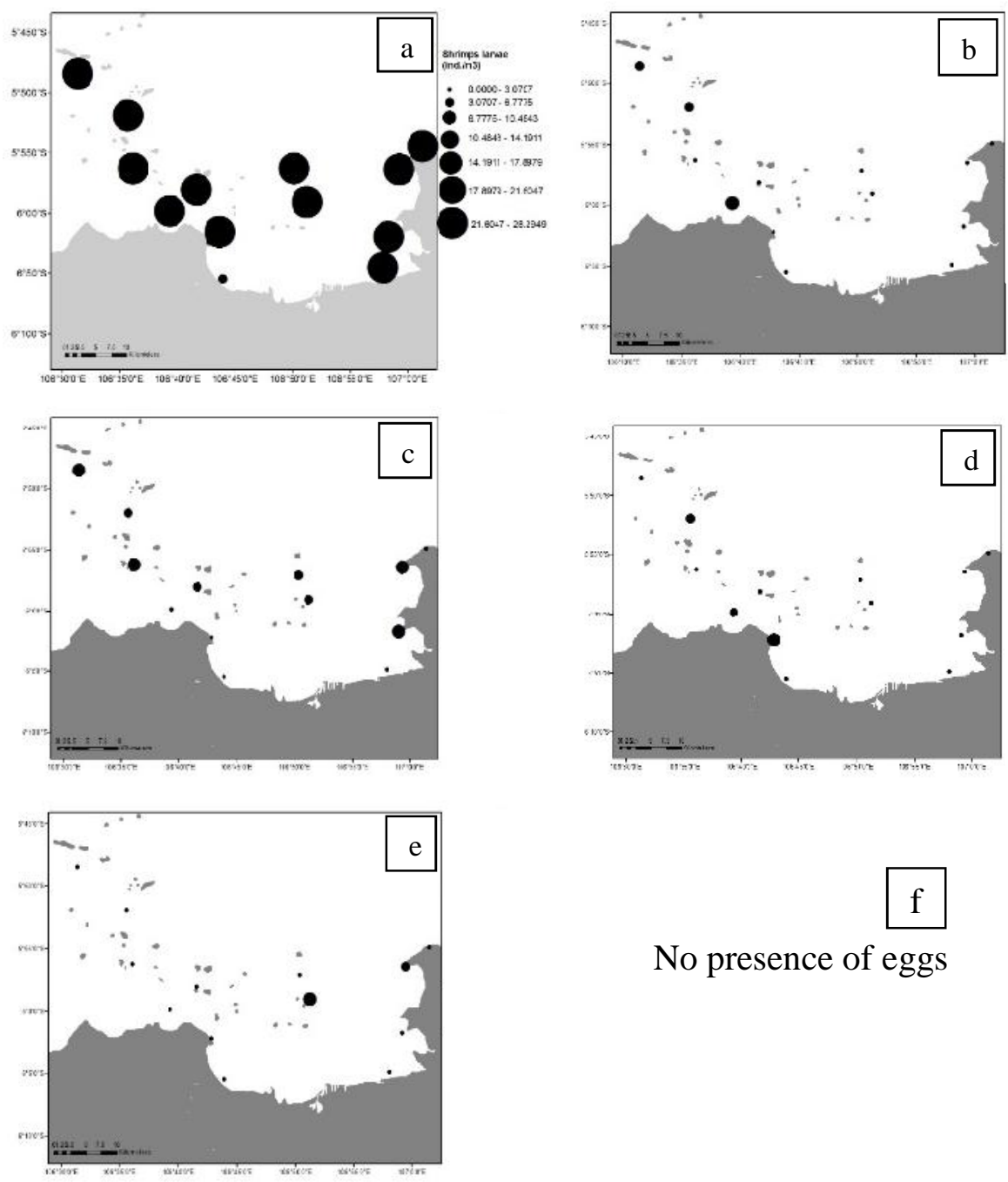

No presence of eggs

No presence of other larvae

Figure 4. Variation on the distribution of group larvae in April (a shrimp larvae; b. crab larvae; c. fish larvae; d. jelly fish larvae; e. squid larvae; f. eggs; g. others).

Gambar 4. Variasi sebaran kelompok larva pada Bulan April (a. larva udang; b. larva kepiting; c. larva ikan; d. larva ubur-ubur; e. larva cumi-cumi; f. telur ikan; g. lainnya). 

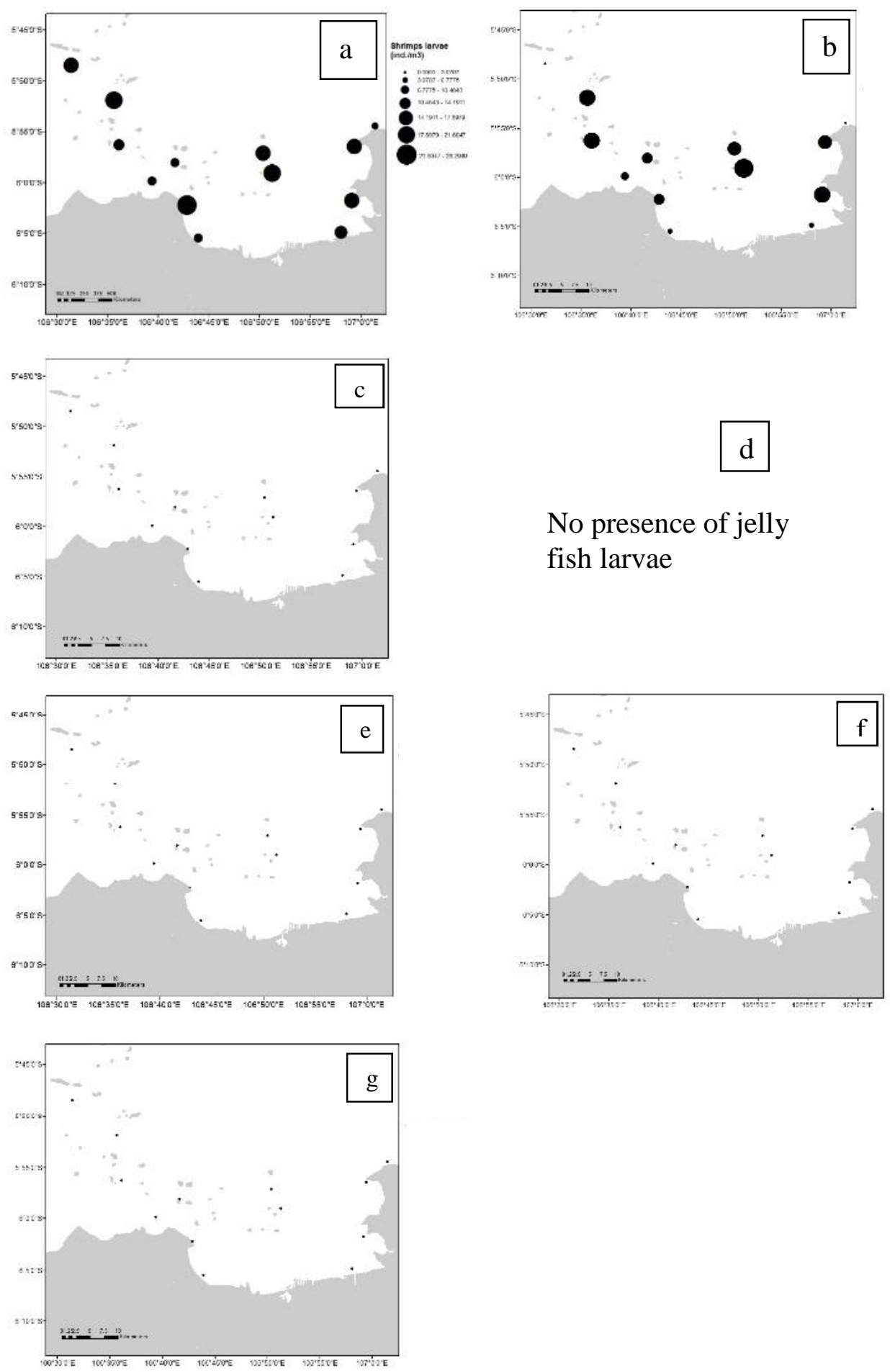

No presence of jelly fish larvae

Figure 5. Variation on the distribution of group larvae in August (a. shrimp larvae; b. crab larvae; c. mollusk larvae; d. jelly fish larvae; e. squid larvae; f. eggs; g. others).

Gambar 5. Variasi sebaran kelompok larva pada bulan Agustus (a. larva udang; b. larva kepiting; c. larva ikan; d. larva ubur-ubur; e. larva cumi-cumi; f. telur ikan; g. lainnya). 
In April, the most abundant of shrimp larvae is found in Damar Kecil Island with $3,060.6 \mathrm{ind} / \mathrm{m}^{3}$, while in August found in Tanjung Rebo with $20.8 \mathrm{ind} / \mathrm{m}^{3}$. The most abundant fish larvae in April was found in Gembong Estuary $\left(3.7 \mathrm{ind} / \mathrm{m}^{3}\right)$ and in Tidung Island $\left(3.5 \mathrm{ind} / \mathrm{m}^{3}\right)$, while in August found in Bahagia Estuary (3.1 $\mathrm{ind} / \mathrm{m}^{3}$ ). The molluscs were found in higher number in the small island stations and estuary stations with the thick mangrove area $(\mathrm{Tj}$. Anom and $\mathrm{Tj}$. Rebo). Crab larvae showed different distribution between April and August. In April, crab larvae only found significantly in $\mathrm{Tj}$. Anom (estuary - mangrove ecosystem), while in August found in all stations. The highest abundance of crab larvae was in Damar Kecil Island (coral reef ecosystem). Squid larvae only present in a small proportion, found in Damar kecil Island, Bahagia Estuary and also Lancang and Pari Island (only present in August). Another additional group found only in April was jelly fish which abundant in $\mathrm{Tj}$. Rebo $\left(3.8 \mathrm{ind} / \mathrm{m}^{3}\right)$.

\section{Grouping of habitat used}

Hierarchical cluster analysis was done based on location. In April, all stations agglomerated into 4 groups, there are Group 1, a big group consisted of 8 stations (combination between estuarine and small island stations); Group 2 consisted of 3 stations categorized as small island; Group 3 and Group 4 were the outlier comprised estuarine station respectively (Figure 6).

Multi-dimentional scaling ordination excluding the 2 outlier stations (Tj. Anom and Tj. Rebo). The MDS model were fit (Stress: 0.133; R: 0.985), grouping 11 stations into three groups. Group 1 comprised estuarine stations (Marunda, Gembong, Bahagia, Buting, and Kamal Estuaries) and small island station (Rambut and Damar Kecil Island), Group 2 comprised small island stations (Pari, Lancang, Damar besar) and Group 3 which was only Tidung Island (Figure 7). Image mapping analysis explained more on the basis of agglomerations group (Figure 8).
MDS ordination shows that larvae attribute does not have a significant characteristic of agglomeration of Group 1 and Group 2 (Figure 7). Hierarchical cluster analysis agglomerates Tidung Island into Group 1, but MDS ordination put. Tidung Island separately with others. Image mapping analysis shows that Tidung Island has different pattern in fish and carb larvae abundance, which is they presence in a higher number compare to other stations in Group 1 (Figure 8c).

Distances among stations in Group 1 are quite small, indicating that Group 1 has higher similarity. There are some adjacent points in Group 1 stations, such as in shrimp, mollusk and crab larvae. Group 1 characterized by significantly high shrimp larvae abundance, low mollusk and crab larvae (Figure 8a). Three stations belong to Group 2 were in one area even though the distance was quite wide within them. Group 2 characterized by low number of fish larvae and higher number of mollusk compare to other stations (Figure 8b).

The grouping pattern of sampling stations in August is quite different with April. Cluster analysis grouped all of the stations into 4 groups, there were Group 1 comprised Marunda Island and Rambut Island stations, Group 2 comprised Bahagia Estuary and Damar Besar Island, Group 3 only consisted of Buting Estuary, and stations belonging to Group 4 were Đamar kecil, Lancang, Tidung, Pari Islands, Tj. Anom, Tj. Rebo, Kamal and Gembong Estuaries (Figure 9).

Multi-dimensional scaling ordination, excluding the only one outlier station namely Buting Estuary. The MDS result showed a bit different pattern with cluster analysis (Figure 10). There are three groups of station; Group 1 consisted of Marunda Estuary which is very close to Kamal Estuary, and Damar Kecil Island, Group 2 consisted of Rambut Island, Pari Island, Gembong Estuary, Tj. Anom, Tj. Rebo and Bahagia Estuary; and Group 3 consisted of Tidung, Lancang and Damar Besar Island. 


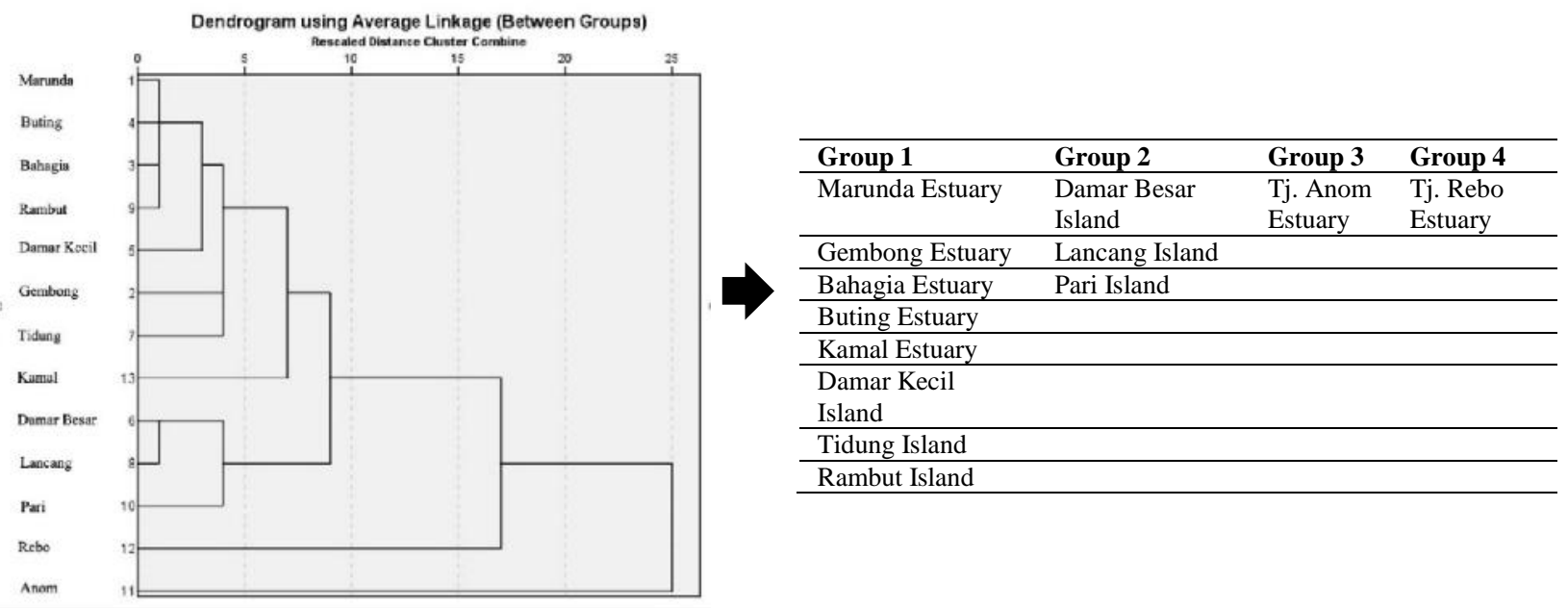

Figure 6. Cluster analysis on April.

Gambar 6. Analisa kluster bulan April

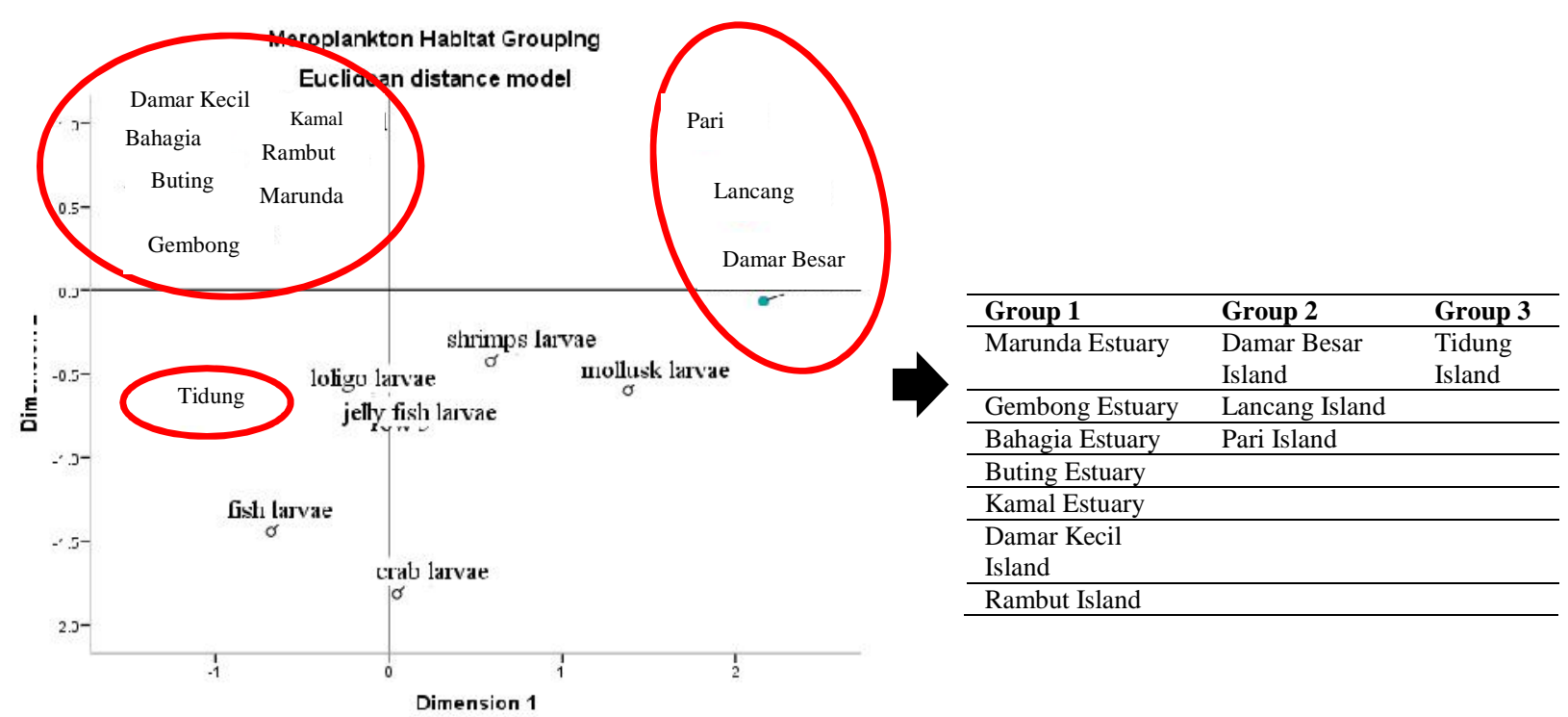

Figure 7. Multidimensional scaling ordination on April Gambar 7. Ordinasi multidimensional scaling pada April
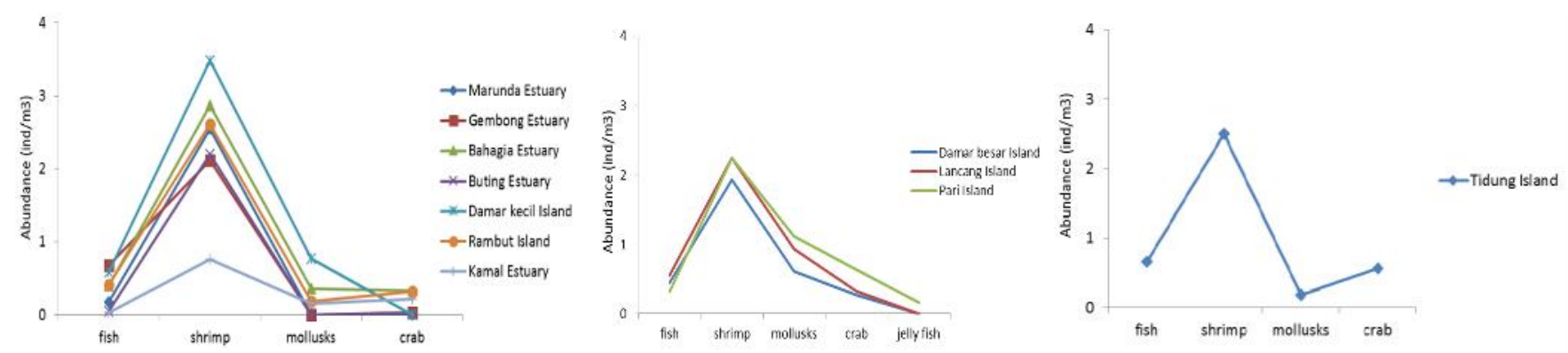

Figure 8. Image mapping analysis for Group 1 (a), Group 2 (b) and Group 3 (c).

Gambar 8. Analisis image mapping untuk kelompok 1 (a), kelompok 2 (b) dan kelompok 3 (c). 


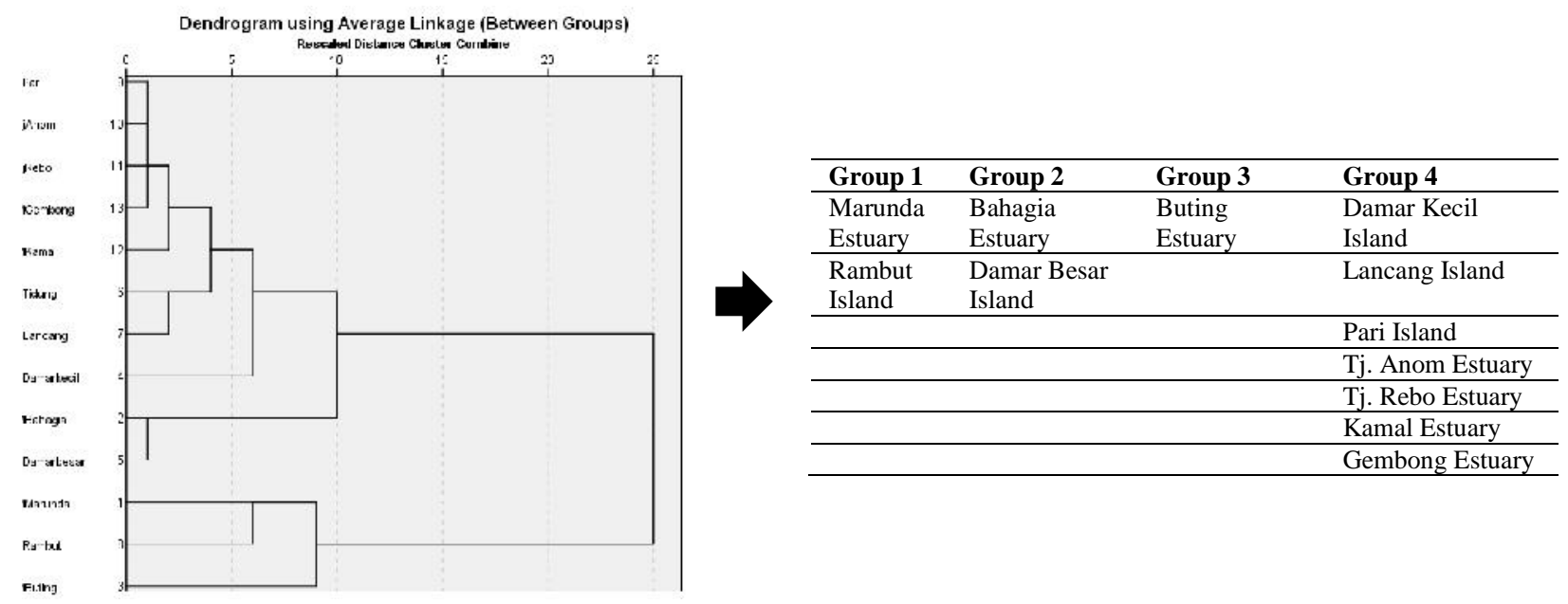

Figure 9. Cluster analysis on August

Gambar 9. Analisa kluster pada Agustus

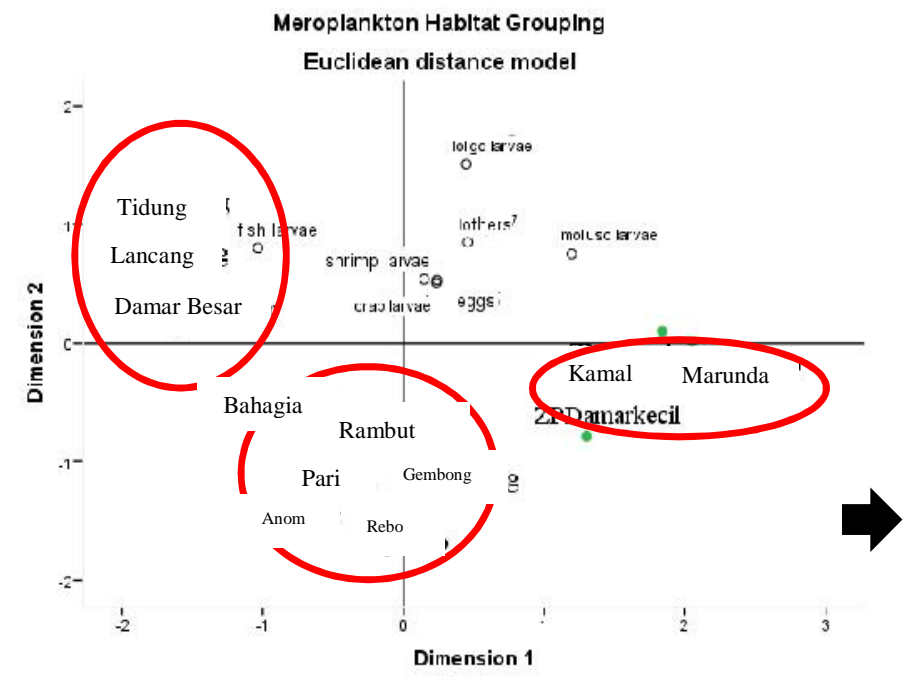

\begin{tabular}{lll}
\hline Group 1 & Group 2 & Group 3 \\
\hline Tidung Island & Rambut Island & $\begin{array}{l}\text { Marunda } \\
\text { Estuary }\end{array}$ \\
\hline $\begin{array}{l}\text { Lancang } \\
\text { Island }\end{array}$ & Pari Island & $\begin{array}{l}\text { Kamal } \\
\text { Estuary }\end{array}$ \\
\hline $\begin{array}{l}\text { Damar Besar } \\
\text { Island }\end{array}$ & Gembong Estuary & \\
\hline \multicolumn{3}{c}{} \\
\hline & Tj. Anom Estuary \\
\hline & Tj. Rebo Estuary \\
\hline & Bahagia Estuary \\
\hline \multicolumn{3}{c}{ Damar Kecil Island } \\
\hline
\end{tabular}

Figure 10. Multidimensional scaling ordination on August Gambar 10. Ordinasi multidimensional scalling pada Agustus
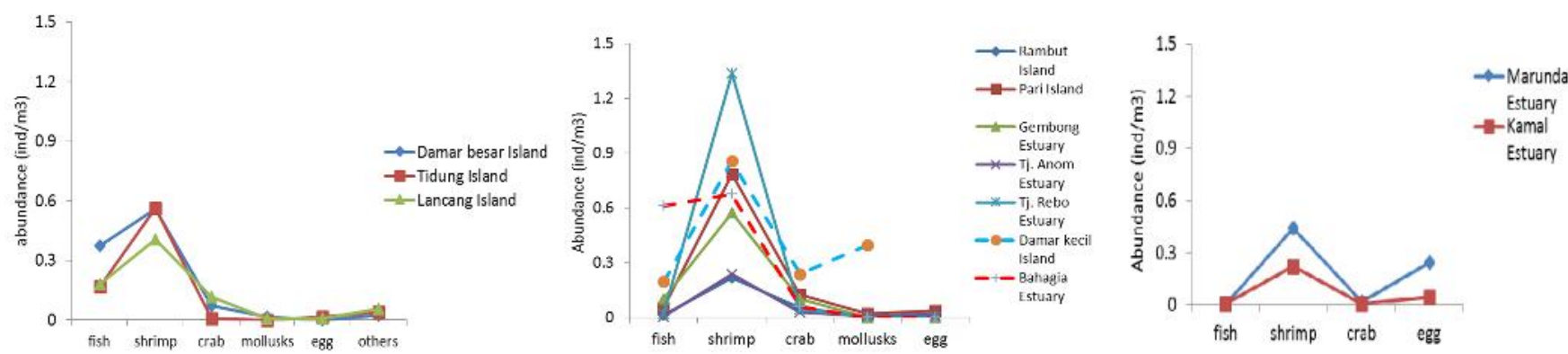

Figure 11. Image mapping analysis for Group 1 (a), Group 2 (b) and Group 3 (c).

Gambar 11. Analisis image mapping untuk kelompok 1(a), kelompok 2(b) dan kelompok 3(c). 
Figure 10 shows that there is fish larvae attribute lays next to Group 1, indicating that Group 1 characterized by fish larvae abundance. Image mapping of Group 1 (Figure 11a) shows that fish larvae presence in higher abundance compare to other larvae. Two of three stations have adjacent point in fish larvae abundance and agglomeration of Group 1 also characterized by similar composition of mollusk, egg and other larvae, which presence in low abundance. MDS model and image mapping of Group 1 shows that Damar Besar, Tidung and Lancang Island used to be fish larvae habitat respectively.

Group 2 is the agglomeration of five stations (Rambut and Pari Island, Gembong Estuary, Tj. Anom and Tj Rebo) which are close one another in ordination, combine with 2 other stations (Bahagia Estuary and Damar Kecil Island) which have a bigger distance with others, but lays in the same dimension. Figure 10 shows that Group 2 is in line with shrimp and crab larvae. Image mapping analysis of Group 2 (Figure 11b) shows that most of the stations characterized by high shrimp larvae abundance, and the presence of crab larvae in higher abundance compare to others. Only Tj. Anom and Rambut Island is low in shrimp larvae abundance. The other points are fish, mollusks and egg, which presence in low number, and become the basis of group agglomeration. Group 3 comprise (s) Marunda and Kamal Estuary, which has 2 adjacent points there are fish larvae and crab abundance. These two stations have similarity in low abundance of fish and crab larvae.

Agglomeration of all sampling stations into some groups, do not show any specific pattern which distinguish estuarine and small island stations. According to the abundance and ordinations of larvae attributes, seems that all larvae have a random distribution and did not show any preferences to specific stations. However fish, shrimp, mollusk and crab larvae mostly used small islands stations (Lancang, Tidung, Damar Besar, Damar Kecil, Rambut) as their habitat, which havehigh temperature and salinity. Small Island is a vegetated habitat which provides numerous benefits including structural refuge from predators and food sources (Martin 2016). The main food source of larvae is zooplankton (Jackson and Lenz 2016). Low abundance of zooplankton in small island stations, indicating that there were high predations processes as previous discussion.

\section{Discussion}

\section{Environment condition}

The presence of meroplankton in some areas related to the spawning season. Adult organism used to find a convenient space to release their eggs, with attributes that favor reproductive success through higher egg survival (Bellier et al. 2007). Spawning ground offers favorable environmental conditions which correspond to frontal zones (Munk et al. 2009), transitional area between water masses such as tidal coast, estuary (Munk and Nielsen, 2005) and upwelling.

Species that has a local distribution like most of reef species, commonly their larvae does not distribute to remote area (El-Regal 2017; Puspasari et al. 2013), It has specific mechanism to stay in coral reef ecosystem (Brogan 1994). Otherwise, the larvae of most pelagic species disperse to other area, influencing by current pattern and the presence of favourable food availability. According to Pineda et al. (2007), meroplankton transport results from complex interaction of biological traits (e.g. spawning time and location, larvae behavior, planktonic larvae duration) and hydrodynamic processes and both vary at several spatial and temporal scales.

The current pattern of Jakarta Bay is influenced by seasonal variation (Setyawan and Putri 1998) and tidal cycle (Sanusi et al. 2005). According to Sanusi et al (2005), tidal current in Jakarta Bay inflows from eastern part of mouthbay and outflows to western part of mouth-bay during flood tide. Reversely, the tidal current inflows from western part of mouth-bay and outflows to eastern part of mouth-bay during ebb tide. Setyawan and Putri (1998) showed that current in Jakarta bay during spring flood condition flow from north Tanjung Pasir to east and during spring ebb the current flow from offshore entering the bay. During neap flood, the current flows from north border of western part and turn left to the west passing through Untung Jawa Island.

Koropitan et al. (2009) showed that most of the pattern in surface residual circulation in Jakarta Bay likely induced by monsoon winds. In April, South East Monsoon (SEM) is influencing Jakarta Bay, which corresponded to lower speed wind and the calmer sea condition. The calm situations support the survival rate of meroplankton and limit their distribution affecting to the high abundance of meroplankton. Koropitan et al. (2009) showed that while SEM current flows westerly, it could become a mechanism to disperse planktonic organism from eastern area to the western part. However, meroplankton abundance were higher in eastern 
area (Marunda, Gembong and Buting Estuary) rather than in western area (Kamal Estuary, Tj. Rebo, Tj. Anom, Lancang and Rambut Island). According to Ayata et al. (2011) hydrological environment alone was insignificant in meroplankton distribution, while geographical space played an important role in larvae distribution, probably in conjunction with ecological process, such as adult population condition and spawning time event.

Results showed that April has lower temperature and salinity than August. The condition indicated that April has a higher rainfall than August, which influenced the temperature and salinity. April is used to be a southeast monsoon, which has a lower rainfall than August, however in the sampling period (2014) there was an anomaly in climate, which was weak La Nina period occurred in April - June, and changed into El Nino period started from July - December (NOAA 2016). La Nina events impacted to higher precipitation (enhancing rain fall over the Western equatorial pacific region include Indonesia), while El Nino events are the reverse. Temperature is one of the key factors determining larva distribution; Michelle et al. (2012) showed that temperature influences the vertical distribution of gastropoda larvae.

Another factor influencing the distribution of meroplankton is the availability of food source. McManus and Woodson (2012) explained that the distributions of plankton (larvae) are highly dependent upon the smaller scale interactions between the individual organisms and its environment such as food source. Zooplankton is a food source of meroplankton (marine larvae), most of marine larvae feed on micro and meso zooplankton (Puspasari 2012; Jackson and Lenz 2016). Food availability played an important role in meroplankton distribution. There is a correlation between food availability and reproductive strategy of many marine organisms. Generally, adult organisms spawn when the environment is favorable for the larvae, and the food availability for the larvae was abundance. Papiol et al. (2014) showed that temporal trend in gonadosomatic index of some species correlated to food availability.

Result showed that the abundance of zooplankton was higher in August while meroplankton population was in a lower number than April. High abundance of meroplankton in April suppressed zooplankton population and their growth particularly in small islands station. The abundance of meroplankton was lower in estuarine station which affecting the lower predatory effect to zooplankton rather than in small island stations. Estuarine is the high nutrient area due to river discharge, which provides a good condition for phytoplankton which is the prey for zooplankton. Low predatory effect and a good food supply lead to good growth of zooplankton resulting in abundance population of zooplankton in estuarine area.

There are some other mechanisms for meroplankton particularly fish larvae to find their microhabitat, Barth et al. (2015) reviewed multiple cues used by fish larvae such as visual, chemical and acoustic cues in dispersal orientation.

\section{Taxonomic Composition, Abundance and Distribution}

Meroplankton collected by using a bongo net composed of six groups of larvae that are shrimp, fish, mollusk, crab, squid, jelly fish and fish egg. Shrimp larvae were dominating the meroplankton composition both in April and August. The results agreed with previous result in 2010 - 2011 and 2014 (Nastiti et al. 2016). A total larva found in April is 92.3 times higher than in August. The higher abundance of total larvae indicating that April is a post spawning season for some groups of species. The previous data in 2010 (Nastiti et al. 2016) showed different condition, that meroplankton abundance in August was higher than April. As previously stated that in 2014, there was an anomaly condition in climate due to El Nino Shouthern Oscillation (ENSO).

In April, the most abundant of shrimp larvae is found in Damar kecil station with 3,060.6 ind $/ \mathrm{m}^{3}$, while in August found in $\mathrm{Tj}$. Rebo with $20.8 \mathrm{ind} / \mathrm{m}^{3}$, means that abundance of shrimp larvae in April reach more than 117 times higher than in August. Previous data (Nastiti et al. 2016) showed that the maximum shrimp larvae abundance found was $0.07 \mathrm{ind} / \mathrm{m}^{3}$ around Gembong and Karawang Estuary characterized by mangroves area. There are some possibilities to explain the difference condition between previous result in 2009 and the present data such as the difference in larvae stage. Shrimp used to spwan in offshore (Niamaimandi et al. 2008) then the egg and larvae drift to coastal area, as their growth they go father to coastal area and utilize mangroves as nursey habitat for juvenile (Sheaves et al. 2012), however the smaller larvae of shrimps found abundantly in coral reef ecosystems.

The most abundant fish larvae in April were found in Gembong Estuary $\left(3.7 \mathrm{ind} / \mathrm{m}^{3}\right)$ and 
in Tidung Island $\left(3.5 \mathrm{ind} / \mathrm{m}^{3}\right)$, while in August found in Bahagia Estuary $\left(3.1 \mathrm{ind} / \mathrm{m}^{3}\right)$. According to Potts and Swaby, 1993, marine fish occurring in estuarine habitat may be attributed to: a) Fully estuarine fish is living almost their entire life-cycle in estuarine habitats; b) Diadromous fish is migrating through estuaries; c) Marine fish is visiting estuarine habitats to feed; d) Marine fish is utilizing estuarine habitats as nursery grounds; e) Fully marine species which are recorded occasionally in estuaries.

The molluscs were found in higher number in the small island and estuary with thick mangrove area ( $\mathrm{Tj}$. Anom and $\mathrm{Tj}$. Rebo), indicating that molluscs choose small island and estuary with thick mangrove as nursery ground. According to Marte and Chia (1991) bivalve and gastropod larvae passed the planktonic larvae by drifting in water colomn and accomplished the dispersal by juvenile.

\section{Conclusion}

The abundance of shrimp, mollusk and fish larvae are higher in April than August, indicating that April is a time after spawning season, while crab spawning season has occured before August. Shrimps, fish and mollusks larvae have no specific preferences in habitat used, however they mostly used small island stations as their habitat compare to estuary, which has high temperature and salinity. The distribution of meroplankton is more related to the pattern of circulation and the food source availability.

\section{Acknowledgements}

This paper is a part of the research result of Research Centre for Fisheries Management and Conservation, 2014, with the title "The assessment of fisheries and environment condition of Jakarta Bay".

\section{References}

Ayata S.D., R. Stolba, T. Comtet and E. Thiebaut. 2011. Meroplankton distribution and its relationship to coastal mesoscale hydrological structure in the northern Bay of Biscay (NE Atlantic). Journal of Plankton Research 33 (8): 1193-1211.

Barth P., I. Berenshtein, M. Besson, N. Roux, E. Parmentier, B. Banaigs and D. Lecchini. 2015. From the ocean to a reef habitat: how do the larvae of coral reef fishes find their way home? A state of art on the lat est advances. Vie et milieu - Life and environment 65 (2): 91-100.

Bellier E., B. Planque, and P. Petitgas. 2007. Historical fluctuations in spawning location of 60 anchovy (Engraulis encrasicolus) and (Sardina pilchardus) in the Bay of Biscay during 1967-73 and 2000-2004. Fisheries Oceanography 16: 1-15.

Brogan M.W. 1994. Distribution and retention of larval fishes near reefs in the Gulf of California. Marine ecology Progress Series 115: $1-13$.

El-regal Abu. 2017. Spatial and temporal distribution of larvae of coral reef fishes in northern red Sea, Egypt. Iranian Journal of Fisheries Science. 1693: 1043-1062.

Heat M.R. 1992. Field Investigations of early life stages of marine fish. Advance in Marine Biology 28: 1 - 174 .

Herman R.T. 2010. Penerapan model multidimensional scaling dalam pemetaan brand positioning internet service provider. Journal The Winners 11 (1): 81 - 93.

NOAA. 2012. Shouthern Oscillation Index. https://www.ncdc.noaa.gov/teleconections/en so/indicators/soi/. 28 Mei 2016.

Jackson J.M. and P.H. Lenz. 2016. Scientific Report of predator-prey interactions in the plankton: larval fish feeding on evasive copepods. Sci. Rep. 6, 33585; doi: 10.1038/srep33585. $11 \mathrm{pp}$.

Koropitan A.F., M. Ikeda, A. Damar and Y. Yamanaka. 2009. Influences of physical processes on the ecosystem of Jakarta Bay: a coupled physical-ecosystem model experiment. ICES Journal of Marine Science 66: 336-348.

Marte A and F.S. Chia. 1991. Drifting and dispersal of small bivalves and gastropods with direct development. Journal of Experimental Marine Biology and Ecology 150:131-147.

Martin C.W. 2016. Experimental evidence that habitat-specific chemical cues influence fish preference patterns. PeerPrePrints 4:e1685v1.https://doi. org/10.7287/peerj.preprints. 20 pp.

McManus M.A. and C.B. Woodson. 2012. Plankton distribution and ocean dispersal. Review. The Journal of Experimental Biology 215: 1008 - 1016. DOI: 10.1242/jeb.059014.

Michelle L.J., M. Anna and D.Y. Brad. 2012. Physical and Biological factors affect the vertical distribution of larvae of benthic gastropods in shallow embayment. Marine Ecology Progress Series 464: 135 - 168.

Munk P. and J. Nielsen. 2005. Eggs and Larvae of North Sea Fishes. Biofolia 215 pp.

Munk P., C.J. Fox, L.J. Bolle, C.J.G. Van Damme, P. Fossum and G. Kraus. 2009. 
Spawning of North Sea fishes linked to hydrographic features. Fisheries Oceanography 18: 458-469.

Nastiti A, N.N. Wiadnyana, B. Badruddin, B. Sumiono, S.T. Hartati, A. Nurfiarini, A. Suryandari, H. Saefulloh dan A. Fitriyanto. 2010. Distribusi spasial dan temporal juvenil udang dan karakteristik habitat secara horizontal dalam rangka konservasi di Teluk Jakarta. Laporan akhir Balai Riset Pemulihan Sumber Daya Ikan Pusat Penelitian Pengelolaan Perikanan dan Konservasi Sumber Daya Ikan. Badan Penelitian dan Pengembangan Kelautan dan Perikanan. Kementerian Kelautan dan Perikanan. 84 pp.

Nastiti A.S., M.R.A. Putri dan S.T. Hartati. 2016. Relationship between abundance of meroplankton and water quality in Jakarta Bay. BAWAL 8 (2): 91-100.

Niamaimandi, N, A. Aziz, D. Siti Khalijah, S. Che Roos and B. Kiabi. 2008. Reproductive biology of the green tiger prawn (Penaeus semisulcatus) in coastal waters of Bushehr, Persian Gulf. ICES Journal of Marine Science 65: 1593-1599.

Pineda J., J. Hare and S. Sponaugle. 2007. Larval transport and dispersal in the coastal ocean and consequences for population connectivity. Oceanography 20: 22-39.

Potts G.W. and S.E. Swaby. 1993. Review of the status of estuarine fishes. English Nature Research Report (34). 278 pp.

Puspasari R., A. Damar, M.M. Kamal, D.T.F. Lumban Batu, N.N. Wiadnyana dan M.
Taufik. 2013. Dinamika larva ikan sebagai dasar opsi pengelolaan sumberdaya ikan di laguna Pulau Pari Kepulauan Seribu. Jurnal Kebijakan Perikanan Indonesia 5(1): $1-7$.

Puspasari R. 2012. Trofodinamik FitoplanktonZooplankton sebagai Penentu Kelangsungan Hidup Larva Ikan di Laguna Pulau Pari Kepulauan Seribu. Disertasi. Sekolah Pascasarjana. Institut Pertanian Bogor. 219 pp.

Sanusi H., A.F. Koropitan, Haeruddin dan A.K. Nugraha. 2005. Pemodelan Pola Arus dan Sebaran Konsentrasi Tembaga ( $\mathrm{Cu}$ ) Terlarut di Teluk Jakarta. Ilmu Kelautan 10 (3):165 168.

Setiawan A. dan M.R. Putri. 1998. Study of current circulation in Jakarta Bay. Proceedings of the 3rd International Symposium on Advanced and Aerospace Science and Technology in Indonesia. Agency for Assessment and Application of Technology. p 803-810.

Sheaves M., R. Johnston, R.M. Connolly and R. Baker. 2012. Importance of estuarine mangroves to juvenile banana prawns. Estuarine, Coastal and Shelf Science 114:208219.

Somarakis S., P. Drakopoulos and V. Filippou. 2002. Distribution and abundance of fish larvae in northern Aegean Sea - eastern Mediterranian in relation to early summer oceanographic condition. Journal of Plankton Research 24 (4): 339 - 357. 